\title{
GCU
}

Glasgow Caledonian

University

University for the Common Good

\section{Can community interventions change resilience? Fostering perceptions of individual and community resilience in rural places}

Markantoni, Marianna; Steiner, Artur Adam; Meador, John Elliot

Published in:

Community Development

DOI:

$10.1080 / 15575330.2018 .1563555$

Publication date:

2019

Document Version

Author accepted manuscript

Link to publication in ResearchOnline

Citation for published version (Harvard):

Markantoni, M, Steiner, AA \& Meador, JE 2019, 'Can community interventions change resilience? Fostering perceptions of individual and community resilience in rural places', Community Development, vol. 50, no. 2, pp. 238-255. https://doi.org/10.1080/15575330.2018.1563555

\section{General rights}

Copyright and moral rights for the publications made accessible in the public portal are retained by the authors and/or other copyright owners and it is a condition of accessing publications that users recognise and abide by the legal requirements associated with these rights.

Take down policy

If you believe that this document breaches copyright please view our takedown policy at https://edshare.gcu.ac.uk/id/eprint/5179 for details of how to contact us. 
Please cite as:

Markantoni, M. Steiner, A., Meador, J. (2019) Can community interventions change resilience? Fostering perceptions of individual and community resilience in rural places, Community Development: Journal of the Community Development Society.

\section{Can community interventions change resilience? Fostering perceptions of individual and community resilience in rural places}

Dr. Marianna Markantoni, Communities in Control, 23 Belgrave Road, Edinburgh, EH12 6NG, UK

Dr. Artur Adam Steiner, Glasgow Caledonian University, M201 George Moore Building, Cowcaddens Road, Glasgow, G4 0BA, UK

Dr. John Elliot Meador, SRUC, Kings Buildings, West Mains Road, Edinburgh EH9 3JG, UK

\section{ABSTRACT}

Governments move away from their roles as providers and take on roles as facilitators and enablers. Such transformations provide opportunities for individuals to play an active role in improving the resilience of their communities. However, the effects of such transformations may not be experienced by all communities equally. In the light of the emerging enabling state, which entails a more pro-active type of community, this article examines whether community projects can enhance the resilience of hard-to-reach rural communities. Analysis from 345 interviews with rural residents from six communities shows that successful completion of community projects can positively change perceptions of resilience, whereas uncompleted projects negatively affect perceptions of resilience. We conclude that for some hard-to-reach communities, in order to build their resilience, continuous funding support needs to be in place. To enhance the resilience of rural communities, the state must also create opportunities for effective community participation.

Keywords: Community resilience; community interventions; enabling state; EU LEADER program; individual resilience 
Please cite as:

Markantoni, M. Steiner, A., Meador, J. (2019) Can community interventions change resilience? Fostering perceptions of individual and community resilience in rural places, Community Development: Journal of the Community Development Society.

\section{Introduction}

The livelihoods of communities all over the world are increasingly undergoing transformations that often amplify social, cultural, environmental, and economic vulnerabilities (Gray, 2002). The combined effects of national and local stressors such as economic, social, and natural hazards mean that central governments will no longer be able to achieve their goals on their own. Prolonged austerity measures (Pierson, 2001) require welfare states of affluent societies to make their localities more sustainable. The need to mobilize diverse community actors working together is widely acknowledged as a means to address socioeconomic and environmental challenges (Marinetto, 2003; Zebrowski \& Sage, 2016).

In recent decades, society has been experiencing a sociocultural shift in which it is moving away from being passive and dependent on the state to being more active and selfreliant. This shift is articulated in many policy and community interventions seeking to strengthen resilience and foster community-led development (Wright, 2016).

In the wake of the enabling state, Cope, Leishman, and Starie, (1997) argue that we need a state "able to enable," one that creates opportunities for engagement at the level of communities, neighborhoods, families, and individuals. Expanding this argument, Elvidge (2014) talks about a new role for government as facilitator and enabler rather than provider and manager. Zebrowski and Sage (2016) take a more critical stance and note that local communities have emerged as a principal target of contemporary empowerment and resilience programs, with such policies going beyond community preparedness and aiming to "responsibilize" individual citizens for the future of their locality.

The policy focus on fostering community-led development continues in the context of reduced public expenditure. Many scholars (Shortall, 2008) highlight the need for inclusive civic 
Please cite as:

Markantoni, M. Steiner, A., Meador, J. (2019) Can community interventions change resilience? Fostering perceptions of individual and community resilience in rural places, Community Development: Journal of the Community Development Society.

engagement that ensures that community participation does not only favor the well-resourced and affluent communities. Shucksmith (2010, p. 215) further argues that marginalized communities are less likely to participate in local development processes "unless explicit attention is given to their inclusion." Communities with well-established partnerships and networks are more often successful in pursuing their development goals (Shucksmith, 2010). While the role of the state in public service provision is weakening, more affluent communities with greater institutional capacity defend their interests and pursue their objectives by taking advantage of remaining government schemes (Wright, 2016). So does this mean that more opportunities are offered to those who experiment while others fall behind? Or should we help

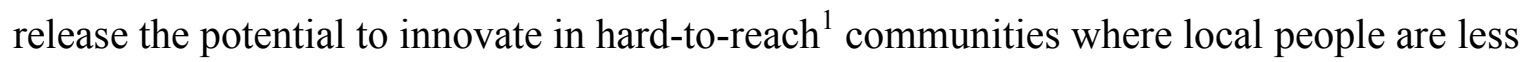
engaged in community development?

In light of the transition towards the enabling state, the purpose of this study is to evaluate resilience outcomes of a rural capacity-building program. The aim of this article is to examine whether externally funded interventions can change or influence perceptions of community and individual resilience among rural residents in hard-to-reach communities. A better understanding of how local residents' perceptions of resilience change over time can help shed light on the type of interventions needed to foster rural resilience. In other words, do rural communities with low levels of civic engagement need externally funded program to improve their resilience?; and what type of support, if any, is required to enhance resilience at individual and community levels? This article answers the above questions by evaluating the Capacity for Change (C4C) community intervention in Dumfries and Galloway region in the southwest of Scotland. C4C was facilitated by the European Union (EU) funding scheme for rural development called LEADER. C4C ran over a two-year period (2011-2013) and aimed to 
Please cite as:

Markantoni, M. Steiner, A., Meador, J. (2019) Can community interventions change resilience? Fostering perceptions of individual and community resilience in rural places, Community Development: Journal of the Community Development Society.

enhance community resilience and to build the capacity of hard-to-reach rural communities (see the forthcoming Is LEADER in line with an enabling state? section for details).

For the purpose of this study, we developed an analytical tool to examine how the implementation of a local community project affects residents' perceptions of individual and community resilience in three main domains according to Wilson (2012a): social, environmental, and economic. The tool measures community and individual resilience based on multiple indicators under the three domains from Wilson (2012a). In this article, we compare the difference between resilience indicators for communities that completed and those that did not complete their projects.

\section{An enabling type of Scottish government?}

In the wake of welfare state restructuring, policies in the UK, and Scotland in particular, are shifting from paternalistic passive approaches towards citizen participation in the co-design and co-production of services (Christie, 2011; Steinerowski \& Woolvin, 2012). Increasingly, governments consider participation and local initiatives in the delivery of services to be key instruments for making communities and regions resilient (Farmer, Hill, \& Munoz, 2012).

Scotland has been supporting an asset-based approach to community development and renewal of its public services. The "Scottish model" advocates a collectivist approach to public services (Markantoni, Steiner, Meador, \& Farmer, 2018). This includes the abolition of departmental structures, the agreement between the Convention of Scottish Local Authorities (COSLA) and the Scottish government to focus on Single Outcome Agreements for all 32 Local Authorities, and the development of Community Planning Partnerships which are an expression of direct engagement for communities in setting local priorities (Carnegie UK Trust, 2013; Scottish Government, 2016). 
Please cite as:

Markantoni, M. Steiner, A., Meador, J. (2019) Can community interventions change resilience? Fostering perceptions of individual and community resilience in rural places, Community Development: Journal of the Community Development Society.

This Scottish approach to public policy creates opportunities for strengthening local democracy and shifting the focus to more asset-based and place-based community action. The Scottish government (2016) is aiming to achieve positive change by tapping into local resources and knowledge of local people. The birth of the Scottish Rural Parliament in 2014 is also a manifestation of representation for rural Scotland to influence "big policies" on rural community empowerment and to strengthen local democratic structures in rural locations.

In light of the preceding discussion, one question that arises is whether Scotland can restructure its public policies towards a more inclusive and enabling state and abolish a “command and control" approach (Edwards, 2009). Is it fair and realistic to rely solely on communities to solve their own problems and make them accountable and responsible for local development? Within this transformative transition, the state does not shoulder the main responsibility of supporting resilience in communities but, instead, relies heavily on people on the ground (Edwards, 2009). Coaffee, Murakami-Wood, and Rogers (2008, p. 3) are critical of this development and argue that:

"Resilience cannot simply be left to communities themselves but requires steering, not rowing, from state level in some form of collaborative alliance to be successful. Arguably, the building of such resilience will be most effective when it involve[s] a mutual and accountable network of civic institutions, agencies and individual citizens working in partnership towards common goals within a common strategy."

In the following sections, we examine this issue of "responsibilising" and discuss whether communities (especially the hard-to-reach ones) can enhance their resilience on their own or 
Please cite as:

Markantoni, M. Steiner, A., Meador, J. (2019) Can community interventions change resilience? Fostering perceptions of individual and community resilience in rural places, Community Development: Journal of the Community Development Society.

whether external support in the form of community interventions is needed to enhance their capacity.

\section{Multiple understandings of community resilience}

\section{Multiple dimensions of resilience}

Resilience is described in many different ways and as "different kinds of things" (Anderson, 2015 , p. 60). The concept is interdisciplinary and is evident in geography, economy, sociology, psychology, ecology, physics, engineering, and disaster and natural hazard studies (Coaffee et al., 2008; Porter \& Davoudi, 2012; Wilkinson, 1991). Despite the popularity of the concept of resilience, scholars have not yet answered the fundamental question of what makes some communities more resilient than others (Steiner, 2016; Wilson, 2010). This is especially the case when applied to people and their environments; resilience is not easily captured or described in a single definition (Norris, Stevens, Pfefferbaum, Wyche, \& Pfefferbaum, 2008). Definitions of the term therefore vary widely according to the contexts and disciplinary fields in which it is deployed. There are divergent voices regarding resilience among policymakers, academics and practitioners, as well as contingencies in the performance of resilience in everyday life.

There is however a strand of recent literature that, rather than attempting to pin down a singular definition of resilience, has sought to understand how a multiplicity of "resiliences" articulates different forms of governance and socio-economic assemblages. Walker and Cooper (2011, p. 144) argue that resilience is more than one thing, suggesting that there may be various types or forms of resilience at a time in which it has become "a pervasive idiom of global governance". While there is much merit in the various articulations of defining resilience, in this paper we adopt the view that there are multiple resiliences and that resilience is not a singular or a fixed entity. 
Please cite as:

Markantoni, M. Steiner, A., Meador, J. (2019) Can community interventions change resilience? Fostering perceptions of individual and community resilience in rural places, Community Development: Journal of the Community Development Society.

The concept of resilience is also gaining currency in the field of community and rural development studies (Amir, Ghapar, Jamal, \& Ahmad, 2015; Fischer \& McKee, 2017; Kulig, Edge, Townshend, Lightfoot, \& Reimer, 2013; Magis, 2010; Matarrita-Cascante, Trejos, Joo, \& Debner, 2016; Steiner \& Markantoni, 2014). Still, Imperiale and Vanclay (2016) call for more research into how resilience comes about in rural areas.

\section{Conceptualizing and operationalizing community resilience}

Community resilience is generally perceived to promote greater wellbeing (Aked, Marks, Cordon, \& Thompson, 2010) by creating common objectives and encouraging community members to work together for the common good of their place. In this context, rural community resilience is often defined as both a "personal" and a "collective" capacity to respond to change (Rennie \& Billing, 2015; Steiner \& Markantoni, 2014). This understanding of resilience links with the definition offered by Magis (2010, p. 402) who suggests that "members of resilient communities intentionally develop personal and collective capacity that they engage to respond to and influence change, to sustain and renew the community and to develop new trajectories for the communities' future." Magis introduces a new understanding of community resilience by including human agency (collectively and individually), proactivity and social capital. Although the literature is still inconclusive about what resilience really means, to operationalize the concept of resilience in this study, we adapt Magis's (2010) definition.

In addition to individual and collective levels of understanding of rural community resilience (Magis, 2010), Wilson (2012b, p. 123) argues that community resilience is best conceptualized on the basis of "how well the critical triangle of economic, social and environmental capital is developed in a given community and how these capitals interact." Wilson $(2014$, p. 7$)$ explains in his conceptual model that "the strongest resilience is achieved when all three critical capitals are 
Please cite as:

Markantoni, M. Steiner, A., Meador, J. (2019) Can community interventions change resilience? Fostering perceptions of individual and community resilience in rural places, Community Development: Journal of the Community Development Society.

equally well developed, i.e. multifunctional communities that incorporate several social, economic, and environmental "functions" simultaneously and that do not rely on only one capital asset." The concepts of resilience and capitals are, therefore, interlinked and should be discussed together as one influences the other.

We recognize there are arguably many types, dimensions and models of resilience. For the purpose of this paper, we explore economic, social and environmental dimensions of selfreported resilience (based on Wilson, 2012b; 2014) at community and individual levels (based on Magis, 2010). Building on the conceptual framework for measuring community resilience developed by Steiner and Markantoni (2014), Figure 1 depicts the analytical approach used in this study. Social resilience is measured with the level of community participation, feeling part of the community and the ability of a community to succeed in improving the village.

Environmental resilience is measured with the utilisation of green spaces and appreciation of the natural environment and whether local residents maintain and care for the natural resources. Economic resilience is measured by the utilisation of local skills and knowledge in the village, whether the current services meet community needs, if community groups work together to generate income for their village and whether local communities attempt to improve their economic situation. The set of indicators applied in this research have been co-developed together with LEADER staff working with the communities in this study.

Several key dimensions have been empirically found to enhance the resilience of rural communities. For instance, a person's connection with the land, the feeling of "I belong to this community" (McManus, 2011, p. 21), the ability of community members to work together in difficult times (Schwarz et al., 2011), and the presence of diverse types of businesses and 
Please cite as:

Markantoni, M. Steiner, A., Meador, J. (2019) Can community interventions change resilience? Fostering perceptions of individual and community resilience in rural places, Community Development: Journal of the Community Development Society.

employment opportunities (Steiner \& Atterton, 2015) all define elements of thriving local communities.

Figure 1. Components of resilience (adapted from Steiner \& Markantoni, 2014).

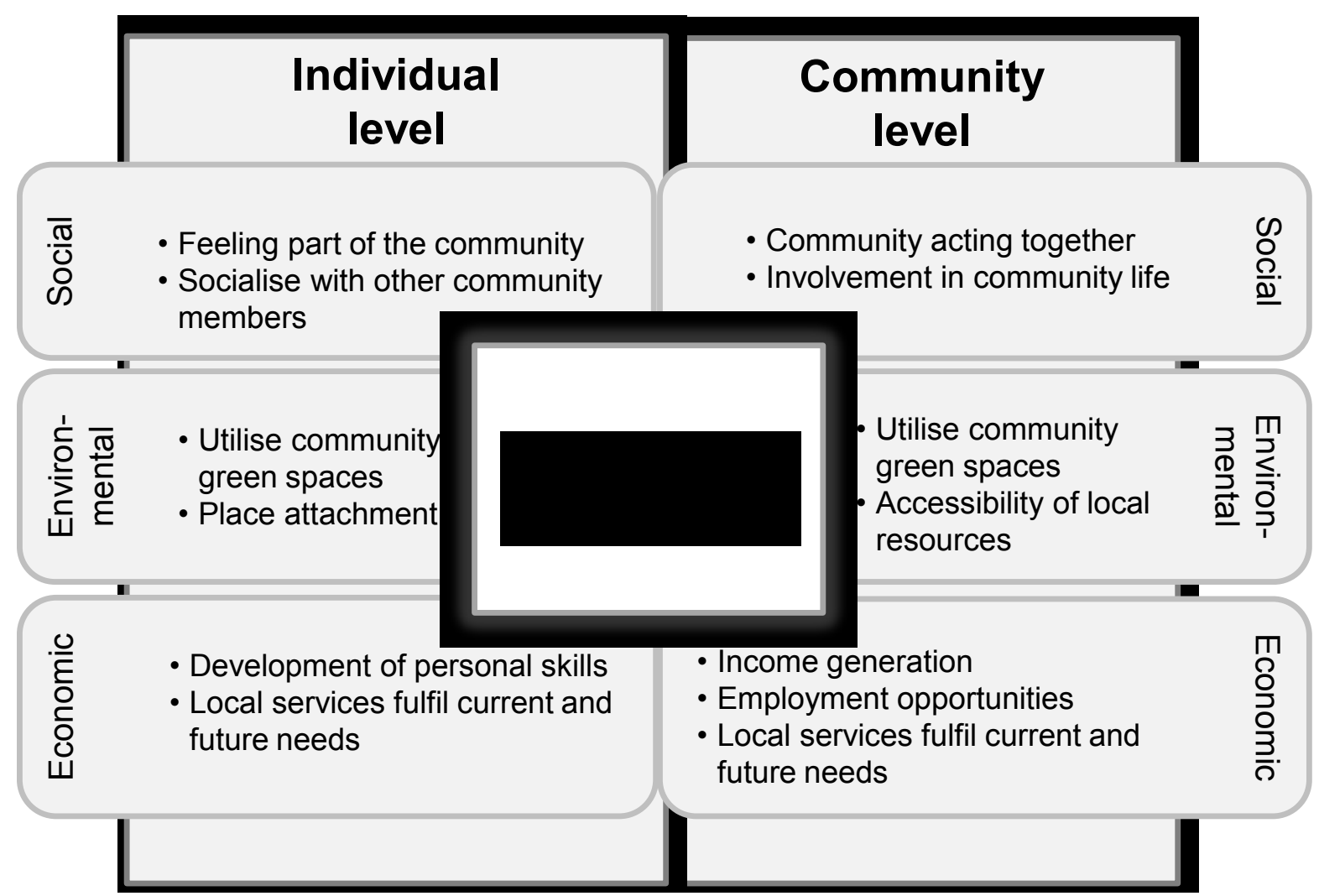

Is LEADER in line with an enabling state?

\section{LEADER approach to community development}

To be successful, rural communities build on networks within and beyond their locality. These networks should include a variety of actors at different governance levels (Bock, 2016; Wright, 2016). The role of the state as enabler and facilitator is crucial in creating opportunities for communities to take part in networked developments (Shucksmith, 2012). 
Please cite as:

Markantoni, M. Steiner, A., Meador, J. (2019) Can community interventions change resilience? Fostering perceptions of individual and community resilience in rural places, Community Development: Journal of the Community Development Society.

To that end, the LEADER approach is increasingly recognized as a networked development enabling active public engagement and participatory governance: “joining together local aspiration with assets within and beyond the territory in a process of mobilisation of place, space and democratic decision-making" (Shucksmith, 2012, p. 12). LEADER (a French acronym meaning links between actions for the development of the rural economy) is a European Union initiative that supports rural development and revitalization at the local level. The program was introduced in 1991 and since then it has provided funding to thousands of community development projects across EU countries, bringing together public, private, and civil-society stakeholders. The aim of LEADER is to find innovative solutions to rural economic and social challenges which best suit specific areas, and to serve as a model for developing rural areas elsewhere (Shucksmith, 2010).

Over the last 20 years, the LEADER approach to Community-Led Local Development (CLLD) has helped rural actors capitalize on the potential of their locality and it has assisted the delivery of development policies in rural Europe (EC, 2014). The aims of CLLD are to (i) encourage local communities in developing bottom-up approaches, (ii) build community capacity and stimulate innovation, (iii) promote community ownership, and (iv) assist multi-level governance. These features are consistent with the overarching aims of an enabling state model and LEADER philosophy guiding the building of community resilience.

Although LEADER supports rural development, LEADER funding is available only to communities that skilfully develop community-development project ideas. The implementation of a project takes place when a community project application is successfully reviewed and a match-funding to support the project secured. Communities applying for LEADER funding but without the skills to generate a project idea cannot qualify for this community development 
Please cite as:

Markantoni, M. Steiner, A., Meador, J. (2019) Can community interventions change resilience? Fostering perceptions of individual and community resilience in rural places, Community Development: Journal of the Community Development Society.

programme. This leaves less capable communities without the support and opportunities for generating local development (Steiner, 2016).

\section{Capacity for change}

Capacity for Change $(\mathrm{C} 4 \mathrm{C})$ represents one of the LEADER-funded projects that was implemented in the southwest of Scotland. C4C was developed to identify effective strategies for sustainable rural development and to address potentially widening disparities between "strong and capable" and "weak and less capable" communities (Steiner, Woolvin \& Skerratt, 2018). Run over a two-year period (2011-2013), C4C's objective was to build the capacity of communities that (i) had no engagement history with LEADER or other major funding streams, (ii) had lost some or the majority of local services in recent years and were perceived locally as disadvantaged, and (iii) were rural and small (fewer than 500 inhabitants).

Through direct financial investments and the engagement of the LEADER project manager, C4C aimed to enhance inclusivity and resilience and, as a consequence, empower selected communities. As opposed to other LEADER initiatives, C4C guaranteed financial and mentoring support to C4C communities: communities were offered up to $£ 20,000$ to develop local projects and the assistance of a project manager to facilitate the implementation of a community project idea. C4C funding regulations stipulated that all projects had to be completed within a 2-year period.

C4C could be seen as one response to a critique of LEADER: that it is the most privileged who are able to win funding, since they already have a greater capacity to act (building on previous successful applications). C4C was designed to address some of the challenges associated with the current UK and Scottish policies, investigating whether the policy for 
Please cite as:

Markantoni, M. Steiner, A., Meador, J. (2019) Can community interventions change resilience? Fostering perceptions of individual and community resilience in rural places, Community Development: Journal of the Community Development Society.

"responsibilising" communities is a realistic one. We present findings that highlight aspects of dependency culture, community empowerment and resilience.

\section{Methods and research approach}

\section{Study context}

Implemented in Dumfries and Galloway, a rural region in the south-west of Scotland, the C4C project took place in six communities whose population density was approximately one-third of the Scottish average, and whose Gross Value Added ${ }^{2}$ per head of population was below the national average. The area is characterized by regional decline, and an ageing and dispersed population. According to the Scottish Index of Multiple Deprivation (Scottish Government, 2017), one of the communities lies in the $20 \%$ to $40 \%$ range of the most deprived areas in Scotland, and the remaining communities are in $40 \%-60 \%$ group of the most deprived areas. These features suggested that selected locations could benefit from the $\mathrm{C} 4 \mathrm{C}$ program. The names of the villages are not mentioned due to confidentiality issues.

\section{Data collection and analysis}

The evaluation of $\mathrm{C} 4 \mathrm{C}$ consisted of a longitudinal mixed methods research approach in which selected community members were interviewed twice - before and after the $\mathrm{C} 4 \mathrm{C}$ intervention, with an additional qualitative sub-sample of interviews to assess in more detail the complexities of $\mathrm{C} 4 \mathrm{C}$ community development process. Firstly, and before the $\mathrm{C} 4 \mathrm{C}$ intervention took place, we conducted interviews and gathered quantitative and qualitative baseline data from participating $\mathrm{C} 4 \mathrm{C}$ communities. The formulation of our interview questions was based on the community resilience literature review and refined through discussions with rural community members and regional community development officers ${ }^{3}$. Respondents provided answers using the Likert scale 
Please cite as:

Markantoni, M. Steiner, A., Meador, J. (2019) Can community interventions change resilience? Fostering perceptions of individual and community resilience in rural places, Community Development: Journal of the Community Development Society.

from zero (very negative) to ten (very positive). In addition, respondents gave qualitative information explaining their numeric responses. The interviews aimed to identify self-reported level of individual and community resilience and the questions referred to social, economic and environmental dimensions. Secondly, when community projects were sufficiently developed, we conducted in-depth interviews with $\mathrm{C} 4 \mathrm{C}$ community members on how change happens, who facilitates the community development process and why it is/is not possible. This helped to reveal aspects of people's motivation and willingness to support projects such as $\mathrm{C} 4 \mathrm{C}$. Finally, after the implementation of $\mathrm{C} 4 \mathrm{C}$, we applied our baseline interview questions to as many interviewees as possible from the initial sample. This longitudinal approach enabled us to measure self-reported changes in the level of community resilience.

To identify C4C community respondents, snowball sampling was adopted. The initial respondents were randomly selected from a list of potential interviewees provided by the $\mathrm{C} 4 \mathrm{C}$ project manager. Interviewed $\mathrm{C} 4 \mathrm{C}$ community members were those involved in the development of, or who could benefit from, the $\mathrm{C} 4 \mathrm{C}$ project. In each $\mathrm{C} 4 \mathrm{C}$ community, we collected views from approximately $10 \%$ of the local population and our data analysis aimed to identify patterns across the data. The sample frame consisted of community members with diverse sociodemographic characteristics (including age distribution, gender, education, employment, health, marital status, origin background, length of stay in a community, and access to a vehicle).

In total, 345 face-to-face interviews with community members were conducted. Interviews lasted 40-60 minutes and were recorded, with consent, and subsequently transcribed. All respondents were ensured anonymity in research outputs. Field notes were also collated and observations recorded. All data were coded, categorized, and analyzed using the constant comparison method and analytic induction. This formed the basis for systematic analysis of 
Please cite as:

Markantoni, M. Steiner, A., Meador, J. (2019) Can community interventions change resilience? Fostering perceptions of individual and community resilience in rural places, Community Development: Journal of the Community Development Society.

transcripts using the N-Vivo qualitative data analysis software program. Statistical information was analysed using SPSS quantitative data analysis software. For the purpose of our data analysis, the communities were divided into two groups: (1) communities which completed and finalized the program within the two-year time frame (labelled as C1, C2, C3), and (2) uncompleted communities which did not manage to finalize the program within the two-year time frame (labelled here as U4, U5, U6). After data cleaning, the "completed-project communities" group included the responses of 81 community members, and 56 community members in the "uncompleted-project communities" group. The analytical framework presented in Figure 1 was used to conduct data analysis focused on ten resilience questions (see Appendix 1). The questions helped to assess social, economic and environmental dimensions of selfreported resilience at community and individual levels.

\section{Analysis and findings}

\section{Resilience change in completed and uncompleted $C 4 C$ projects}

Community members who participated in $\mathrm{C} 4 \mathrm{C}$ identified a variety of ideas for their local projects. These included a community garden with a seaside view (Figure 2), a kitchen facility in a village hall, enhancement of a heritage trail, design and development of a local statue symbolising characteristics of the village, and a forest path linking two villages. While some communities successfully completed their projects within the $\mathrm{C} 4 \mathrm{C}$ lifetime, other struggled to do so. Here we present findings that show whether community interventions can change or influence perceptions of community and individual resilience among rural residents in hard-toreach communities. 
Please cite as:

Markantoni, M. Steiner, A., Meador, J. (2019) Can community interventions change resilience? Fostering perceptions of individual and community resilience in rural places, Community Development: Journal of the Community Development Society.

Figure 2. Opening a new community garden with school pupils helping with the planting.

(Source: The Galloway Gazette, 2013)

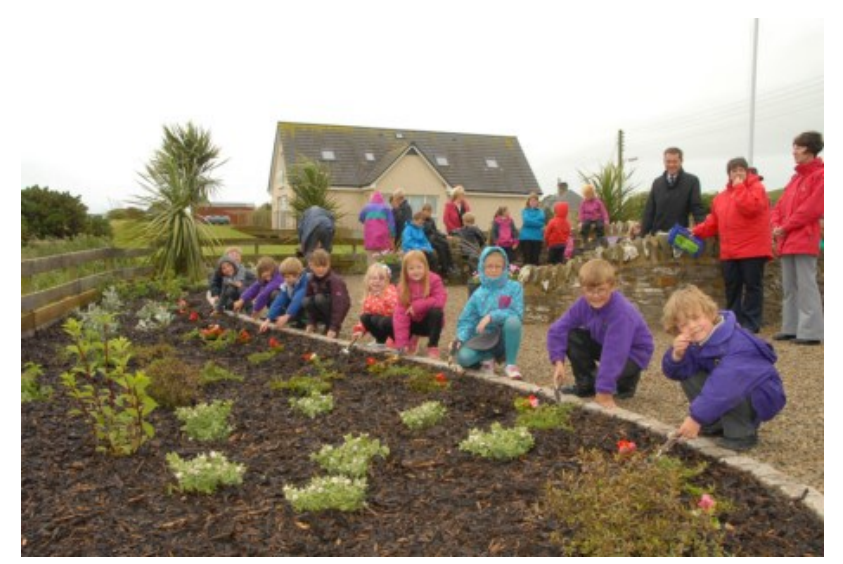

Table 1 presents the change in resilience levels for each resilience variable between the two stages of the study (i.e. before and after C4C intervention). Firstly, a Shapiro-Wilks test of normality was conducted on each variable in addition to a visual inspection of the distribution of each variable using density plots. This test indicates whether a variable is normally distributed or not. The Shapiro-Wilks test and a visual test of each variable's distribution indicate that, while most variables appear to be normally distributed, a chi-square test is an appropriate measure of difference. Chi-square tests of significance were performed for each variable presented in Table 1. The p-values are indicated with asterisks using the conventional approach.

Table 1 grouped our results according to completed and uncompleted projects as well as the change in a particular dimension between stages for each group. Overall, the self-reported resilience scores of communities which completed the $\mathrm{C} 4 \mathrm{C}$ projects increased across the board, except for the Social Individual question: "To what extent are all members in the community encouraged to be involved in community life?" and the Environment Community question: “To what extent do your community members utilize, maintain, and care for existing natural 
Please cite as:

Markantoni, M. Steiner, A., Meador, J. (2019) Can community interventions change resilience? Fostering perceptions of individual and community resilience in rural places, Community Development: Journal of the Community Development Society.

resources in the village?" Neither of these are statistically significant at alpha level 0.05 .

Respondents of uncompleted community projects reported a decrease or no change in all

variables. There are statistically significant changes in the questions: "To what extent are all

members in the community encouraged to be involved in community life?"; "To what extent do your community members utilize, maintain, and care for existing natural resources in the village?"; and, "To what extent do community groups work together to generate income for the village?" The mean score of each of these variables lowered between the two stages.

Table 1. Mean changes in level of social, environmental, and economic resilience.

\begin{tabular}{|c|c|c|c|c|c|c|c|}
\hline \multirow{2}{*}{$\begin{array}{c}\text { Type of } \\
\text { resilience }\end{array}$} & \multirow[b]{2}{*}{ Questions asked } & \multicolumn{3}{|c|}{$\begin{array}{c}\begin{array}{c}\text { Completed } \\
(\mathrm{n}=163)\end{array} \\
\end{array}$} & \multicolumn{3}{|c|}{$\begin{array}{c}\text { Uncompleted } \\
(\mathrm{n}=112)\end{array}$} \\
\hline & & Before & After & Change & Before & After & Change \\
\hline \multirow{2}{*}{$\begin{array}{c}\text { Social } \\
\text { Community }\end{array}$} & $\begin{array}{l}\text { a. To what extent do you } \\
\text { engage with other } \\
\text { members of your } \\
\text { community? }\end{array}$ & $\begin{array}{l}7.1 \\
(1.9)\end{array}$ & $\begin{array}{l}7.4 \\
(2.2)\end{array}$ & 0.3 & $\begin{array}{l}6.9 \\
(2.2)\end{array}$ & $\begin{array}{l}6.8 \\
(1.9)\end{array}$ & -0.1 \\
\hline & $\begin{array}{l}\text { b. To what extent do you } \\
\text { feel part of this } \\
\text { community? }\end{array}$ & $\begin{array}{l}7.3 \\
(2.2)\end{array}$ & $\begin{array}{l}7.8 \\
(1.8)\end{array}$ & $0.5^{*}$ & $\begin{array}{r}7.5 \\
(2.0)\end{array}$ & $\begin{array}{l}7.4 \\
(2.0)\end{array}$ & -0.1 \\
\hline \multirow{2}{*}{$\begin{array}{c}\text { Social } \\
\text { Individual }\end{array}$} & $\begin{array}{l}\text { c. To what extent do you } \\
\text { think your community } \\
\text { succeeds in developing } \\
\text { and improving this } \\
\text { village? }\end{array}$ & $\begin{array}{l}6.2 \\
(2.0)\end{array}$ & $\begin{array}{r}6.7 \\
(2.0)\end{array}$ & 0.5 & $\begin{array}{l}5.5 \\
(2.5)\end{array}$ & $\begin{array}{r}5.3 \\
(2.7)\end{array}$ & -0.2 \\
\hline & $\begin{array}{l}\text { d. To what extent are all } \\
\text { members in the } \\
\text { community encouraged to } \\
\text { be involved in community } \\
\text { life? }\end{array}$ & $\begin{array}{l}7.1 \\
(1.7)\end{array}$ & $\begin{array}{r}6.8 \\
(2.3)\end{array}$ & -0.2 & $\begin{array}{l}6.7 \\
(2.3)\end{array}$ & $\begin{array}{c}5.7 \\
(2.5)\end{array}$ & $-0.9 *$ \\
\hline $\begin{array}{l}\text { Environmental } \\
\text { Individual }\end{array}$ & $\begin{array}{l}\text { f. How much do you use } \\
\text { green spaces and } \\
\text { appreciate the natural } \\
\text { environment in your } \\
\text { community? }\end{array}$ & $\begin{array}{l}7.1 \\
(2.9)\end{array}$ & $\begin{array}{l}8.1 \\
(2.0)\end{array}$ & $1.0 * *$ & (1.4) & $\begin{array}{l}8.3 \\
(2.4)\end{array}$ & -0.4 \\
\hline $\begin{array}{c}\text { Environmental } \\
\text { Community }\end{array}$ & $\begin{array}{l}\text { e. To what extent do your } \\
\text { community members } \\
\text { utilise, maintain and care } \\
\text { for existing natural } \\
\text { resources in the village? }\end{array}$ & $\begin{array}{l}7.3 \\
(1.7)\end{array}$ & $\begin{array}{r}6.9 \\
(2.0)\end{array}$ & -0.3 & $(2.0)$ & $(2.5)$ & $-0.9 *$ \\
\hline
\end{tabular}


Please cite as:

Markantoni, M. Steiner, A., Meador, J. (2019) Can community interventions change resilience? Fostering perceptions of individual and community resilience in rural places, Community Development: Journal of the Community Development Society.

\begin{tabular}{|c|c|c|c|c|c|c|c|}
\hline \multirow{2}{*}{$\begin{array}{l}\text { Economic } \\
\text { Community }\end{array}$} & $\begin{array}{l}\text { f. To what extent do you } \\
\text { use your skills and } \\
\text { knowledge you have in } \\
\text { your village? }\end{array}$ & $\begin{array}{l}5.0 \\
(3.2)\end{array}$ & $\begin{array}{l}6.4 \\
(2.6)\end{array}$ & $1.4 * * *$ & $\begin{array}{l}5.4 \\
(2.7)\end{array}$ & $\begin{array}{l}5.4 \\
(2.7)\end{array}$ & 0 \\
\hline & $\begin{array}{l}\text { h. To what extent do } \\
\text { services and infrastructure } \\
\text { in your village meet your } \\
\text { current and likely future } \\
\text { needs? }\end{array}$ & $\begin{array}{l}5.2 \\
(2.6)\end{array}$ & $\begin{array}{l}5.7 \\
(2.4)\end{array}$ & 0.5 & 6.3 & 5.6 & -0.7 \\
\hline \multirow{2}{*}{$\begin{array}{l}\text { Economic } \\
\text { Individual }\end{array}$} & $\begin{array}{l}\text { i. To what extent do } \\
\text { community groups work } \\
\text { together to generate } \\
\text { income for the village? }\end{array}$ & $\begin{array}{l}5.4 \\
(2.8)\end{array}$ & $\begin{array}{l}6.0 \\
(2.5)\end{array}$ & $0.6^{*}$ & 5.4 & 4.6 & $-0.8^{*}$ \\
\hline & $\begin{array}{l}\text { j. To what extent do you } \\
\text { think your community } \\
\text { makes most of what it has } \\
\text { to improve its economic } \\
\text { situation? }\end{array}$ & $\begin{array}{l}4.1 \\
(2.5)\end{array}$ & $\begin{array}{l}5.3 \\
(2.3)\end{array}$ & $1.3^{*}$ & $\begin{array}{l}5.1 \\
(1.9)\end{array}$ & $\begin{array}{l}4.7 \\
(2.3)\end{array}$ & -0.4 \\
\hline
\end{tabular}

$* \mathrm{p}<.05 ; * * \mathrm{p}<.01 ; * * * \mathrm{p}<.001$; based on chi-square distribution.

Standard deviations are represented in parenthesis

Table 2 shows the reliability score for each resilient type and a 95\% confidence interval for the test statistic. Both community and economic resilience have scores over 0.60 , with a score of 0.67 and 0.65 respectively. Environmental resilience has Cronbach's alpha score of 0.22 , which is too low to indicate any reliable scaling, thus it should not be considered a scaled resilience type in its current form. It is likely that the number of variables included (2) is too low to be considered for scaling in the same way that community resilience and economic resilience are (Brown, 2014). 
Please cite as:

Markantoni, M. Steiner, A., Meador, J. (2019) Can community interventions change resilience? Fostering perceptions of individual and community resilience in rural places, Community Development: Journal of the Community Development Society.

Table 2. Item reliability analysis.

$95 \%$ Confidence interval

\begin{tabular}{r|c|c|c}
\multicolumn{2}{c}{ Cronbach alpha } & Lower bound & Upper bound \\
\cline { 3 - 3 } Scaled item & 0.67 & 0.61 & 0.73 \\
Environmental & 0.22 & 0.15 & 0.30 \\
Economic & 0.65 & 0.59 & 0.72 \\
\hline \hline
\end{tabular}

Note: Environmental resilience type has only two factors.

One conclusion from these initial findings suggests that only completed community C4C projects lead to an increased level of self-reported level of resilience. Communities that do not complete their projects decreased or maintained their level of reported resilience. However, to further interpret the results and understand how community interventions can change or influence perceptions of community and individual resilience among rural residents, we present findings from the qualitative component of the $\mathrm{C} 4 \mathrm{C}$ study. These are summarized in the following sections as social, environmental, and economic resilience at both the community and individual levels.

\section{Social resilience}

Measuring change and the wider impact of the $\mathrm{C} 4 \mathrm{C}$ program, the study found that individual perceptions of social community resilience showed a statistically significant increase in the communities that successfully completed their $\mathrm{C} 4 \mathrm{C}$ projects. The biggest change (and statistical significant at $\mathrm{p}$ 0.05) was seen in the social community question: To what extent do you feel part of this community? 
Please cite as:

Markantoni, M. Steiner, A., Meador, J. (2019) Can community interventions change resilience? Fostering perceptions of individual and community resilience in rural places, Community Development: Journal of the Community Development Society.

However, in uncompleted community projects, all self-reported social resilience variables at both community and individual levels decreased over time (Table 1). The largest decrease occurred in the variable: "To what extent are all members in the community encouraged to be involved in community life?" This question had a decrease of about 0.9 and is statistically significant. It is worth noting the already high levels of social resilience of both completed and non-completed projects. Still, with this high level of overall social resilience, completed projects saw an increase in perceived social resilience, while uncompleted projects saw a decrease.

To understand the phenomenon of resilience in more depth, besides measuring changes between the two stages of the study, the self-reported social resilience of respondents from all participating communities were examined. Respondents were asked to elaborate on their perception of social resilience by discussing their everyday experiences of how they engaged and socialized with other community members. Respondents from both types of communities (completed and uncompleted $\mathrm{C} 4 \mathrm{C}$ projects) mentioned that on a daily basis they visited and helped neighbors (especially the elderly), some volunteered, while others actively participated in local events and in community council meetings. However, in two villages (U4, U5) which did not complete their $\mathrm{C} 4 \mathrm{C}$ projects, respondents elaborated on the tendency "not to get too involved" and "to preserve some distance" from the other community residents. One interviewee mentioned that "going into my neighbor's house was something I generally tried to avoid" (U412). It is interesting to note that in these villages, it was also emphasized that those people who volunteered to support local community centres often created what was described as "closed circles" and that they did not interact with all members of the community, which could have made the other villagers reluctant to participate in wider community affairs. 
Markantoni, M. Steiner, A., Meador, J. (2019) Can community interventions change resilience? Fostering perceptions of individual and community resilience in rural places, Community Development: Journal of the Community Development Society.

In general, across both types of communities with completed and uncompleted C4C projects, the main obstacles hampering participation in community life were the lack of time and busy life schedules, with some expressing a preference for staying at home in the evenings rather than engaging in community life (C1). This approach could be problematic in the long term, because it can lead to the isolation of individuals. The level of solidarity in both types of communities, however, is interesting, especially in relation to caring for the elderly residents. Helping neighbours in times of an emergency, such as power cuts or bad weather conditions (e.g. flooding), and ensuring that everyone in the community is supported and safe, seemed natural to most of the respondents.

Moving our discussion to the level of social community resilience, the findings show a more complex picture. For the question regarding the extent to which a community succeeds in developing and improving its village, we found that the self-reported level of resilience increased across communities with completed $\mathrm{C} 4 \mathrm{C}$ projects and decreased across communities with uncompleted projects. However, the extent to which members of the community felt encouraged to get involved in community life saw a decrease in all participating communities in our study. This decrease was small and not found to be statistically significant in completed projects. Whilst, for uncompleted projects, the decrease was substantial and significant (about 0.9); overall, completed projects have a higher overall mean between both rounds as compared to uncompleted projects. This suggests that even capacity-building projects, such as $\mathrm{C} 4 \mathrm{C}$, do not necessarily help to integrate all community members but only subgroups within communities. Those who do not participate in local projects might be under the impression that there is no external encouragement to be actively involved in community life.

\section{Environmental resilience}


Please cite as:

Markantoni, M. Steiner, A., Meador, J. (2019) Can community interventions change resilience? Fostering perceptions of individual and community resilience in rural places, Community Development: Journal of the Community Development Society.

Results of the self-reported change in environmental resilience at the individual level show that only communities that successfully completed their C4C projects scored high in the question concerning the utilisation of green spaces and appreciation of the natural environment (Table 1); this increase is statistically significant at alpha level 0.01 . These findings were to be expected especially because some $\mathrm{C} 4 \mathrm{C}$ projects were related to connecting communities with nature (e.g. a community garden and a forest-path linking two villages). However, the changing dimensions of environmental resilience at the community level are less evident.

At the environmental community level, the findings indicate that the extent to which community members utilized, maintained, and cared for existing natural resources in their villages decreased in all communities studied (both completed and uncompleted C4C projects), although the decrease in this component of self-reported resilience was lower in the former communities (i.e. 0.2), than in the latter communities, (i.e. 0.9). The negative change observed in communities with completed $\mathrm{C} 4 \mathrm{C}$ projects suggests that implementation of a local project does not guarantee that all community members will utilize and/or care about its outputs.

When respondents were asked to elaborate on how community members helped to improve the environment, it was mentioned that in general residents "keep the village tidy, maintain community grounds and play areas for children well, and help to create an attractive environment for visitors and residents" (U4-20). In one of the communities that did not complete the C4C project, the community council managed to secure money to purchase land for a recreation ground for kids (U4-23), which shows that creating outdoor space is important to local residents. The following quote from a respondent of the same community is illustrative:

Such efforts continue to inspire [us] to improve other facilities in the village ... but it depends if we got finance for it. We can try to generate income but we need sponsors (U4-19). 
Markantoni, M. Steiner, A., Meador, J. (2019) Can community interventions change resilience? Fostering perceptions of individual and community resilience in rural places, Community Development: Journal of the Community Development Society.

Results from the qualitative data show that for both types of communities, with completed and uncompleted $\mathrm{C} 4 \mathrm{C}$ projects, the local environment and nature were highly valued and that all communities strived to enhance the surroundings of their communities by securing finance to buy community-owned land, maintaining community gardens and creating an attractive place to live in.

\section{Economic resilience}

The self-reported economic resilience, at both the community and individual levels, increased in the communities which completed the $\mathrm{C} 4 \mathrm{C}$ projects and decreased or stayed the same in the communities which did not complete $\mathrm{C} 4 \mathrm{C}$ projects (Table 1). Although $\mathrm{C} 4 \mathrm{C}$ helped to develop small-scale projects that did not aim directly at economic revitalization, it seems that $\mathrm{C} 4 \mathrm{C}$ brought hope for positive economic change. At the same time, individual participants' perceptions and attitudes related to resilience for uncompleted $\mathrm{C} 4 \mathrm{C}$ projects had a negative impact on the economic resilience. It is interesting to note that respondents from completed $\mathrm{C} 4 \mathrm{C}$ community projects scored higher in the question of utilising skills in their village, when compared with respondents from uncompleted community projects. The mean increase is 1.4 and statistically significant. This is the largest increase in any measured variable for both completed and uncompleted projects. It might be that $\mathrm{C} 4 \mathrm{C}$ helped community members to utilize their skills during the setting up and development of local projects such as utilising financial or project management skills. Indeed, respondents from communities with uncompleted C4C projects indicated a need for more diverse ways to increase their skills within the villages (see Table 3). This could mean that more tailored support, such as training opportunities and financial incentives, would be beneficial to economic resilience. 
Please cite as:

Markantoni, M. Steiner, A., Meador, J. (2019) Can community interventions change resilience? Fostering perceptions of individual and community resilience in rural places, Community Development: Journal of the Community Development Society.

Table 3. What would encourage community members to use their skills more widely?

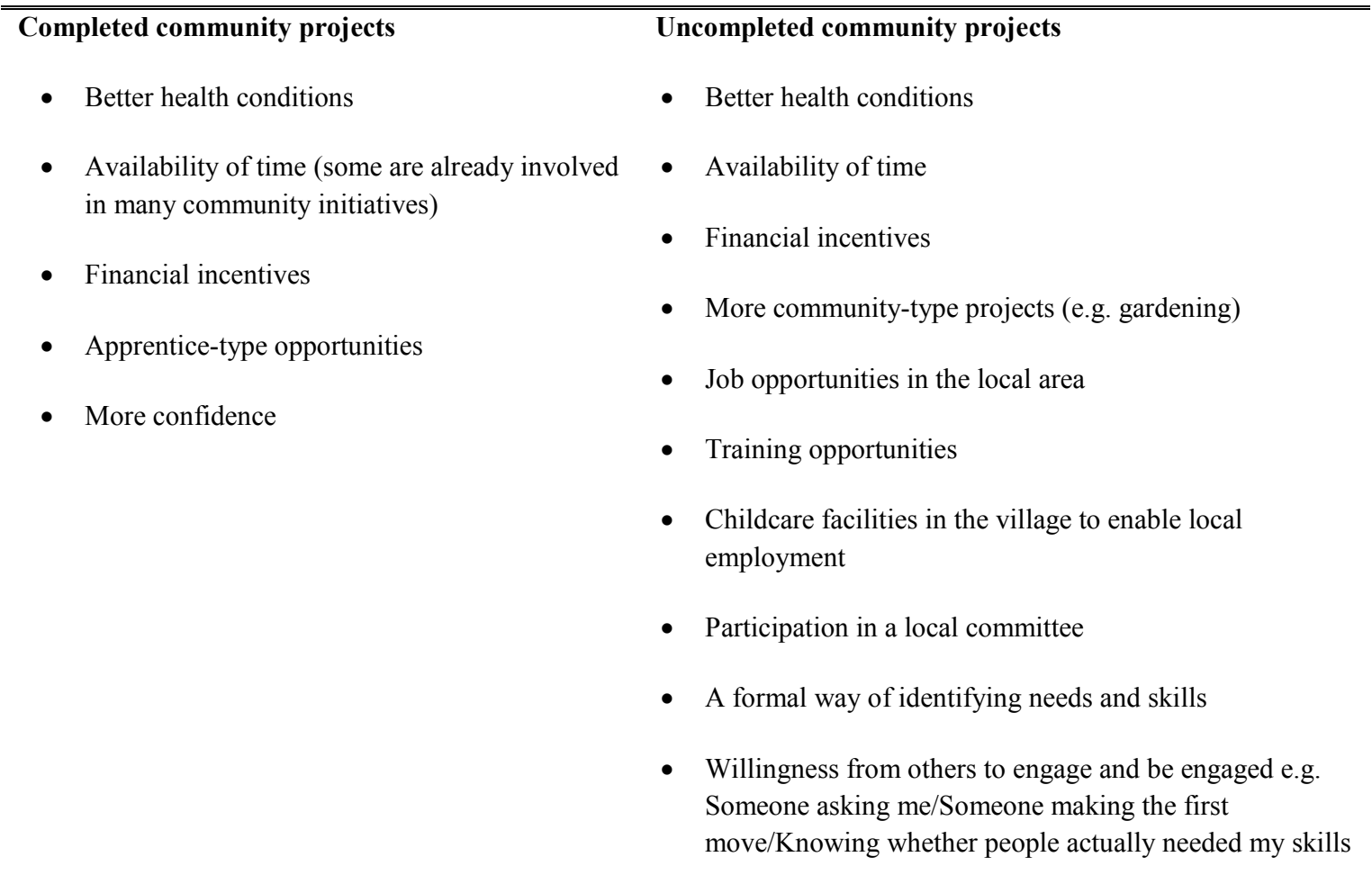

The fact that there are limited services in some communities was not always considered problematic. Respondents claimed that even though they would like to have more shops and facilities in their village, they realized that it was not feasible due to rurality and low population density. Respondents acknowledged that there were good services near their communities, highlighting the importance of interconnectedness for rural locations. While others accepted the loss of the local shops, they also expressed the need for a meeting point in the community to catalyse social interactions. Hence, economic aspects, as suggested, are linked to social resilience.

Respondents from both types of communities (with completed and uncompleted C4C projects), talked about ways in which local services could be improved. However, many services 
Please cite as:

Markantoni, M. Steiner, A., Meador, J. (2019) Can community interventions change resilience? Fostering perceptions of individual and community resilience in rural places, Community Development: Journal of the Community Development Society.

such as digital infrastructure, transport and connectivity services, road infrastructure, and access to healthcare are traditionally provided by regional and national governments, which suggests a continuous need for a high level of state support.

\section{Discussion}

This research adds to the current knowledge base of community resilience by developing an understanding of the effects of community interventions, whether such interventions can change or influence perceptions of community and individual resilience among rural residents in hardto-reach communities. We examined whether the $\mathrm{C} 4 \mathrm{C}$ program influenced aspects of social, environmental and economic resilience at individual and community levels.

Our findings show that, despite being tailored to support the development of skills and building the capacity of communities to empower them, $\mathrm{C} 4 \mathrm{C}$ succeeded in half of the $\mathrm{C} 4 \mathrm{C}$ communities. Those belonging to "the glass is half full" camp might view this a success story; others might argue that investments in development projects in hard-to-reach communities are too risky and not financially sustainable.

The results from the self-assessment of resilience by rural residents in six communities where $\mathrm{C} 4 \mathrm{C}$ was implemented show that, overall, based on the individual participants' perceptions and attitudes related to resilience, communities that completed their projects increased their resilience scores. On the other hand, communities with uncompleted projects self-reported a decrease or no change of resilience in all evaluated variables. We conclude that successful implementation of community projects is an indicator of how communities perceive social, environmental and economic resilience at individual and community levels. We note that the initial self-reported social resilience scores across communities with uncompleted projects were much lower than in 
Please cite as:

Markantoni, M. Steiner, A., Meador, J. (2019) Can community interventions change resilience? Fostering perceptions of individual and community resilience in rural places, Community Development: Journal of the Community Development Society.

the communities with completed projects. This lower and decreasing score could be explained by the fact that in the communities with uncompleted $\mathrm{C} 4 \mathrm{C}$ projects we observed difficulties with social inclusion and community participation; for instance, respondents talked about "closed circles" that made some of them reluctant to participate. It would appear, therefore, that the culture of inclusiveness and openness might influence the outcomes and perception of community development projects.

Interestingly, individual participants' perceptions related to economic resilience at both community and individual levels increased in communities that completed their $\mathrm{C} 4 \mathrm{C}$ projects and decreased in communities that did not complete their projects. It appears that successful completion of C4C-type projects can contribute to creating a positive economic change. Caution is therefore needed when designing and implementing community interventions and care should be taken to ensure their timely completion.

\section{Conclusion}

The study presented has provided a better understanding of how individual participants' perceptions and attitudes related to resilience change over time with regard to community interventions in hard-to-reach communities. Especially in communities with little or no engagement as collectives, support is needed not only in financial terms to initiate community projects, but also to mentor and facilitate the process of project implementation. Any challenging issues faced by community members who run local projects should be resolved in the early stages to prevent problems from escalating. As evidenced in the $\mathrm{C} 4 \mathrm{C}$ study, the engagement of a project officer who facilitates implementation of the project might not be sufficient. 
Please cite as:

Markantoni, M. Steiner, A., Meador, J. (2019) Can community interventions change resilience? Fostering perceptions of individual and community resilience in rural places, Community Development: Journal of the Community Development Society.

Consequently, “enabling” strategies might not always work and more on-going direct state support might be essential to ensure the development of resilient communities.

The state and external funders have a challenging task of navigating between encouraging and facilitating communities to take ownership of local projects and the potential risk of their failure if projects are not completed. Especially in the era of welfare retrenchment, communities where projects are not completed may not only experience the effects of these failures but also encounter an ever-shrinking safety net for the most vulnerable. Although helpful, public grants and support from experienced community development programm such as LEADER do not guarantee the success of projects. Hence, there is a need to work with hard-to-reach communities, to exercise care when designing community interventions, and to set up a contingency plan in case of a project failure. Such a plan could help boost community confidence and remedy any negative effects.

We agree with Elvidge's statement (2014) that the state must take on its new role by empowering communities, families and individuals to play a more active role in improving their own wellbeing. Although the rhetoric behind community engagement and empowerment is positive, capacity building within communities might require both greater state funding and long-term (and therefore costly) interventions. Hence, in times of limited public budgets, rather than saving finances, a higher spending can be anticipated.

While it is useful to assess how the $\mathrm{C} 4 \mathrm{C}$ changed the perceptions of resilience among rural residents in hard-to-reach communities, this does not reveal the long-term impacts of the intervention. It may be that communities that did not succeed in finalising their $\mathrm{C} 4 \mathrm{C}$ projects still learned something new, drawing relevant and useful conclusions from negative experiences that could influence their future projects. At the same time a critical question arises as to what 
Please cite as:

Markantoni, M. Steiner, A., Meador, J. (2019) Can community interventions change resilience? Fostering perceptions of individual and community resilience in rural places, Community Development: Journal of the Community Development Society.

happens when the project support is gone and the project is finalized. It is possible that communities with completed $\mathrm{C} 4 \mathrm{C}$ projects might not be able to run their future projects independently. Secondly, although new policies might not necessarily lead to a more sustainable system, it is hoped that the empowerment agenda will lead to a fairer state. However, as suggested by our findings, power can go to certain subgroups within communities rather than entire communities, causing alienation and lack of integrity in the communities concerned.

Our study generates a number of questions, indicating that there is an on-going need to find better ways of empowering communities, especially hard-to-reach communities. The $\mathrm{C} 4 \mathrm{C}$ approach represents one of many approaches. This is not surprising, as empowerment processes are complex (Skerratt \& Steiner, 2013) and can take place only by creating common objectives and encouraging community members to work together (Aked et al., 2010). The state should not absolve itself from its responsibilities under the banner of neoliberal governmentality (Zebrowski \& Sage, 2016) but instead it should design interventions in partnership with communities (Coaffee et al., 2008).

Concluding, we argue that the process of moving towards resilient communities seems to require a set of appropriate mechanisms at the local level with the right support (financial and others) to build the capacity that enables communities to act and successfully complete their community projects. If we are to redesign the role of the state, then we must create opportunities for meaningful and effective community participation that enhances the resilience of rural communities as well as develop a better understanding of the appropriate level of state support at the local level.

Although relevant to policy, research and practice, there are limitations in the findings presented. Our study was conducted in a specific type of community (i.e. small and with no 
Please cite as:

Markantoni, M. Steiner, A., Meador, J. (2019) Can community interventions change resilience? Fostering perceptions of individual and community resilience in rural places, Community Development: Journal of the Community Development Society.

previous engagement in LEADER or other major funding initiatives) in rural Scotland. Also, our quantitative findings are based on an analytical framework that has not been tested before. We therefore encourage researchers in the field to test the framework and aspects of community resilience in other community settings. 
Please cite as:

Markantoni, M. Steiner, A., Meador, J. (2019) Can community interventions change resilience? Fostering perceptions of individual and community resilience in rural places, Community Development: Journal of the Community Development Society.

\section{References}

Aked, J., Marks, N., Cordon, C., \& Thompson, S. (2010). Five ways to wellbeing. The New Economics Foundation, London: Creative Commons.

Amir, A. F., Ghapar, A. A., Jamal, S. A., \& Ahmad, K. N. (2015). Sustainable tourism development: A study on community resilience for rural tourism in Malaysia. ProcediaSocial and Behavioral Sciences, 168, 116-122. https://doi.org/10.1016/j.sbspro.2014.10.217

Anderson, B., 2015. What kind of thing is resilience?. Politics, 35, 60-66. https://doi.org/10.1111/1467-9256.12079

Bock, B. (2016). Rural marginalisation and the role of social innovation; A turn towards nexogenous development and rural reconnection. Sociologia Ruralis, 56, 552-573. https://doi.org/10.1111/soru.12119

Borda-Rodriguez, A., Johnson, H., Shaw, L., \& Vicari, S. (2016). What makes rural co-operatives resilient in developing countries? Journal of International Development, 28(1), 89-111. https://doi.org/10.1002/jid.3125

Brown, T. A. (2014). Confirmatory factor analysis for applied research. New York: Guilford Publications.

Carnegie UK Trust. (2013). The enabling state in Scotland. Dunfermline: Carnegie UK Trust.

Christie, C. (2011). Commission on the future delivery of public services. Edinburgh: APS Group Scotland.

Coaffee, J., Murakami-Wood, D., \& Rogers, P. (2008). The everyday resilience of the city: How cities respond to terrorism and disaster. London: Palgrave/Macmillan. 
Please cite as:

Markantoni, M. Steiner, A., Meador, J. (2019) Can community interventions change resilience? Fostering perceptions of individual and community resilience in rural places, Community Development: Journal of the Community Development Society.

Cope, S., Leishman, F., \& Starie, P. (1997). Globalisation, new public management and the enabling State. Futures of police management. International Journal of Public Sector Management, 10, 444-460. https://doi.org/10.1108/09513559710190816

Edwards, C. (2009). Resilient nation. London: Demos. https://www.demos.co.uk/files/Resilient Nation - web-1.pdf

Elvidge, J. (2014). A route map to an enabling state. Dunfermline: Carnegie UK Trust. European Commission (EC). (2014). Community-led local development. Cohesion policy 20142020. Brussels: Author.

Farmer, J., Hill, C., \& Munoz, S.-A. (2012). Community co-production. Social enterprise in remote and rural communities. Cheltenham: Edward Elgar.

Fischer, A., \& McKee, A. (2017). A question of capacities? Community resilience and empowerment between assets, abilities and relationships. Journal of Rural Studies, 54, 187-197. https://doi.org/10.1016/j.jrurstud.2017.06.020

Gray, J. (2002). False dawn: The delusions of global capitalism. London: Granta Books.

Imperiale, A. J., \& Vanclay, F. (2016). Experiencing local community resilience in action: Learning from post-disaster communities. Journal of Rural Studies, 47, 204-219. https://doi.org/10.1016/j.jrurstud.2016.08.002

Kulig, J. C., Edge, D. S., Townshend, I. Lightfoot, N., \& Reimer, W. (2013). Community resiliency: Emerging theoretical insights. Journal of Community Psychology, 41, 758775. http://dx.doi.org/10.1002/jcop.21569

Magis, K. (2010). Community resilience: An indicator of social sustainability. Society \& Natural Resources, 33, 401-416. https://doi.org/10.1080/08941920903305674 
Please cite as:

Markantoni, M. Steiner, A., Meador, J. (2019) Can community interventions change resilience? Fostering perceptions of individual and community resilience in rural places, Community Development: Journal of the Community Development Society.

Marinetto, M. (2003). Who wants to be an active citizen? The politics of practice and community involvement. Sociology, 37, 103-120. https://doi.org/10.1177/0038038503037001390

Markantoni, M., Steiner, A., Meador, E., \& Farmer, J. (2018). Do community empowerment and enabling state policies work in practice? Insights from a community development intervention in rural Scotland. Geoforum, 97, 142-154.

https://doi.org/10.1016/j.geoforum.2018.10.022

Matarrita-Cascante, D., Trejos, B., Qin, H., Joo, D., \& Debner, S. (2017). Conceptualizing community resilience: Revisiting conceptual distinctions. Community Development, 48, 105-123. https://doi.org/10.1080/15575330.2016.1248458

McManus, P., Walmsley, J., Argent, N., Baum, S., Bourke, L., Martin, J., ... Sorensen, T. (2011). Rural community and rural resilience: What is important to farmers in keeping their country towns alive? Journal of Rural Studies, 28, 20-29.

http://dx.doi.org/10.1016/j.jrurstud.2011.09.003

Norris, F. H., Stevens, S. P., Pfefferbaum, B. Wyche K. F., \& Pfefferbaum R. L. (2008). Community resilience as a metaphor, theory, set of capacities, and strategy for disaster readiness. American Journal of Community Psychology, 41, 127. https://doi.org/10.1007/s10464-007-9156-6

Pierson, P. (2001). The new politics of the welfare state. Oxford: Oxford University Press.

Porter, L., \& Davoudi, S. (2012). The politics of resilience for planning: A cautionary note. Planning Theory \& Practice, 13, 329-333. http://dx.doi.org/10.1080/14649357.2012.677124

Rennie, F., \& Billing, S-L. (2015). Changing community perceptions of sustainable rural development in Scotland. Journal of Rural and Community Development, 10, 35-46. 
Please cite as:

Markantoni, M. Steiner, A., Meador, J. (2019) Can community interventions change resilience? Fostering perceptions of individual and community resilience in rural places, Community Development: Journal of the Community Development Society.

Schwarz, A., Béné, C., Bennett, G., Boso, D., Hilly, Z., Paul, C., ... \& Andrew, N. (2011).

Vulnerability and resilience of remote rural communities to shocks and global changes:

Empirical analysis from Solomon Islands. Global Environmental Change, 21, 128-1140.

https://doi.org/10.1016/j.gloenvcha.2011.04.011

Scottish Government. (2016). How community planning works. Edinburgh: The Scottish

Government.

Scottish Government. (2017). Scottish index of multiple deprivation. Available at: http://www.gov.scot/Topics/Statistics/SIMD.

Shortall S (2008) Are rural development programmes socially inclusive? Social inclusion, civic engagement, participation, and social capital: Exploring the differences. Journal of Rural Studies, 24, 450-457. https://doi.org/10.1016/j.jrurstud.2008.01.001

Shucksmith, M. (2010). Endogenous development, social capital, and social inclusion:

Perspectives from LEADER in the UK. Sociologia Ruralis, 40, 208-218. https://doi.org/10.1111/1467-9523.00143

Shucksmith, M. (2012). Future directions in rural development? Dunfermline: Carnegie UK Trust 2012.

Skerratt, S., \& Steiner, A. (2013). Working with communities-of-place: Complexities of empowerment. Local Economy, 28, 320-338. https://doi.org/10.1177/0269094212474241

Steiner, A. (2016). Assessing the effectiveness of a capacity building intervention in empowering hard to reach communities. Journal of Community Practice, 24, 235-263.

https://doi.org/10.1080/10705422.2016.1201561 
Please cite as:

Markantoni, M. Steiner, A., Meador, J. (2019) Can community interventions change resilience? Fostering perceptions of individual and community resilience in rural places, Community Development: Journal of the Community Development Society.

Steiner, A., \& Atterton, J. (2015). Exploring the contribution of rural enterprises to local resilience. Journal of Rural Studies, 40, 30-45. https://doi.org/10.1016/j.jrurstud.2015.05.004

Steiner, A., \& Markantoni, M. (2014). Exploring community resilience in Scotland through capacity for change. Community Development Journal, 49, 407-425. https://doi.org/10.1016/j.jrurstud.2015.05.004

Steiner, A., Woolvin, M., \& Skerratt, S. (2018). Measuring community resilience over time: Developing and applying a 'hybrid evaluation' approach. Community Development Journal, 53, 99-118. https://doi.org/10.1093/cdj/bsw017

Steinerowski, A., \& Woolvin, M. (2012). Supporting older people in establishing social enterprises in rural Scotland through action research: Reflections on challenges and opportunities. Families, Relationships and Societies, 1, 277286. https://doi.org/10.1332/204674312X645574

Walker, J., \& Cooper, M. (2011). Genealogies of resilience: From systems ecology to the political economy of crisis adaptation. Security dialogue, 42, 143-160. https://doi.org/10.1177/0967010611399616

Wilkinson, K. (1991). The community in rural America. New York: Greenwood Press.

Wilson, G. (2010). Multifunctional 'quality' and rural community resilience. Royal Geographical Society, 35, 364-381.

Wilson, G. (2012a). Community resilience, globalisation, and transitional pathways of decision making. Geoforum, 43, 1218-1231. https://doi.org/10.1016/j.geoforum.2012.03.008

Wilson, G. (2012b). Community resilience and environmental transitions. London: Routledge. 
Please cite as:

Markantoni, M. Steiner, A., Meador, J. (2019) Can community interventions change resilience? Fostering perceptions of individual and community resilience in rural places, Community Development: Journal of the Community Development Society.

Wilson, G. (2014). Community resilience: Path dependency, lock-in effects and transitional ruptures. Journal of Environmental Planning and Management, 57, 1-26. https://doi.org/10.1080/09640568.2012.741519

Wright, K. (2016). Resilient communities? Experiences of risk and resilience in a time of austerity. International Journal of Disaster Risk Reduction, 18, 154-161. http://dx.doi.org/10.1016/j.ijdrr.2016.06.003

Zebrowski, C., \& Sage, D. (2016). Organising community resilience: An examination of the forms of sociality promoted in community resilience programmes. Resilience, 5, 44-60. https://doi.org/10.1080/21693293.2016.1228158

1 The term 'hard to reach' relates to communities with no history of engagement as collectives.

2 Gross value added is a measure of the increase in the value of the economy due to the production of goods and services.

3 A detailed description of the C4C methodology is presented in Steiner et al. (2018). 